\title{
AESTHETICS AND DAY-LIGHTING CORRELATION: AN EXPERIMENTAL STUDY OF FORM AND PLACEMENT OF WINDOWS ON BUILDINGS
}

\author{
Olusegun Moses Idowu (PhD) $)^{\star 凶}$ and Sumadanda Humphrey \\ Department of Architecture, Modibbo Adama University of Technology, Yola, Nigeria
}

\begin{abstract}
:
Original Article

Design concepts or principles such as 'Form follows function', 'Beauty in usability', or 'Attractive things work better' suggest that a positive correlation exists between aesthetics and functions of a building. Windows are designed probably for aesthetics and daylight in

PII: S238315531800001-7 spaces of a building. However the design of windows for adequate daylight may be antithetical to that of aesthetic enhancement. This study sought to ascertain the effect of window form and position on, and the correlation if any, between aesthetics and daylight in spaces of a building. 143 respondents in four groups who were mainly undergraduate and postgraduate students and lecturers in Architecture were the respondents in the study. Six simulated elevations of an existing building with different form and placement but same window area were ranked in order of aesthetic pleasantness. Six architectural models of a typical room in the building were constructed with the window forms and placement as on the simulated elevations. Day-lighting levels were observed with lux meter outside, and at 16 positions on the floor of the simulated rooms. Mean daylight factors and daylight levels of in the rooms were calculated. Spearman's Rank Order Correlation Coefficients were employed to ascertain correlation between aesthetic rankings of the elevations and respective daylight factors. It was found that window forms and positions affect both aesthetic rankings and daylight factors in rooms of the buildings.

co Correlation coefficients of +0.94 were obtained in three of the four ranking groups, while

Corresponding author: the other ranking group recorded a coefficient of +0.77 . The study concluded that the

E-mail: correlation between aesthetics and day-lighting through window design is at least

idowumosegun@gmail.com appreciable and positive. It was recommended that windows form be rectangular with geometric proportion toward 'the golden ratio'
\end{abstract}

Tel: +2348061510635

KEYWORDS:

Buildings; Window form; Window position; Aesthetics; Day-lighting; Correlation.

\section{INTRODUCTION}

Aesthetics has been referred to as that branch of philosophy dealing with the nature, art, taste and expression of beauty. Involving the study of sensory or sensori-emotional values, it is sometimes described as 'judgement of sentiment and taste' [1, 2], and 'the science of how things are known via the senses' or 'standards of taste' [3]. Environmental aesthetics has also been defined [4] as psychological pleasure sensation towards the environment. Architreacher [5] held that architectural aesthetics is governed by elements such as form, colour, light and shade.

Windows are designed for day-lighting, natural ventilation, outdoor view prospects, and to enhance the aesthetics of buildings [6, 7]. Rich and Dean [8] are of the opinion that the proportions, framing materials and position of windows can influence the feel and quality of spaces in a building. Climatic factors, thermal and visual comfort needs may influence the form, materials and components of windows. The resultant window designs sometimes enhance aesthetics in buildings retrofitted for thermal performance through changes in materials and components of window as reported in Gyimah and Tetlow [9] and Apogee Enterprises [10]. Window design for thermal or visual comfort may also be antithetical or contradictory to aesthetics enhancement. For instance, passive cooling enhancement in the warm-humid and hot-humid climates requires window areas and positions different from those required in the hot-dry and cold-dry climates [11]. Visual comfort challenges may not be equally addressed through daylight in these scenarios.

\section{Windows and day-lighting}

Daylight is admitted into architectural spaces through design of fenestrations in form of sidelighting (wall opening) or top-lighting (roof openings) of buildings [7]. While side-wall windows and clerestory windows are components of sidelighting, monitor light, saw-tooth light, and north roof light are examples of top-lighting. Even though day-light quantum admitted into space partly 
depends on height of fenestration as cited in Abraham [7], Moscoso [12] described windows as the most basic daylight collectors, capable of influencing the aesthetic quality of spaces in a building. Other factors that may affect amount of daylight admission include: intensity and direction of sunlight; luminance (photometric brightness) and luminance distribution of clear, partly cloudy, and overcast skies; surrounding physical features and terrain [6]. The light falling on a point indoors is made of the sky component, the component reflected by interior surfaces, and the component reflected by external surfaces. Daylight factor is a measure of interior day-lighting and defined [13] as a ratio of the light falling on a point indoors to that which would fall on the point from an unobstructed sky.

Daylight influences the pleasantness, excitement, order, complexity, legibility, coherence, spaciousness, openness, and spatial definition of a space [12, 14]. In Abraham [7], day-light is also cited to create healthier and more stimulating work environment, enhance productivity and afford better quality illumination. Efficient Windows Collaborative [15] adds that these attributes are influenced by the size, geometry, distribution and placement of widows on the building. Abraham [7] however warns that visual problems may be created by windows if not fitted with light shelves (Figure 1a) or venetian blinds. Unacceptable brightness levels and excessive contrast ratios of the background to the foreground are among the problems associated with windows.

\section{Windows and aesthetics}

According to Ching [16], the visual properties of shape, size, colour and texture, position, and orientation constitute the form of a building, and that the aesthetics of an architectural form or element is influenced by variables including proportion, scale, balance, rhythm, contrast, and unity. Aesthetic judgement, according to Smith [17], often engages visual proportions at both primary (first-order) and secondary (second-order) levels. In a similar vein, Vitruvius [18] believed that due regard for proportion creates orders and makes architecture beautiful. For him, harmony is achieved only when correct proportions are employed (throughout) from the whole to the individual elements of the building, as evident in the natural proportion of the human body. Often referred to as 'the golden ratio' (harmonic or divine proportional ratio), this natural proportion has been celebrated as the hallmark of aesthetic proportion in historic buildings such as the Pantheon. It is expressed [19] as the proportion of two dimensions such that the ratio of the shorter $(s)$ to the longer $(l)$ is the same as the ratio of the longer to the sum of the shorter and the longer (i.e, $s: l=l:[s+l]$ ). Empirical studies [17, $19,20]$ show that architectural forms with proportions closer to the golden ratio (1: 1.618) are adjudged more aesthetically delightful to beholders from diverse backgrounds. The golden ratio is often correlated with the 'Fibonacci Sequence' of numbers in which each number is the sum of the two preceding

numbers (e.g.,o,1,1,2,3,5,8,13,21,34,65,99,164). The sequence is believed to be exhibited in patterns found in some natural forms including bones in the human hand [19].

The proportional quality of a building is determined in part by the relationship between window and wall. The extent to which a building displays the quality of proportion is an aggregation of characteristics, ranging from the massing of its principal features to the proportion and disposition of windows, the ratio of the ground storey to upper floors and wall to roof. According to Smith [17], the sum of 'window-ness' is pitched against the totality of 'wall-ness', one against the other within the limit of deferential dominance (figures $1 \mathrm{~b} \& \mathrm{1c}$ ). Windows as a discrete feature have significance in terms of proportion. The Georgian and Victorian windows for instance conform to the golden ratio, but differ sharply in aesthetic value due to the difference in number of their panes (Figure 1d).

Eurythym and symmetry are related criteria for judging the beauty of the design. Eurythym is the right relationship, proportional as well as formal, of the parts of an individual element (such as window). Symmetry on the other hand is the right relationship of individual elements to the composition as a whole. For Vitruvius, symmetry is the most important aesthetic quality in a building, and it is the harmonious correlation of proportions throughout a design [18].

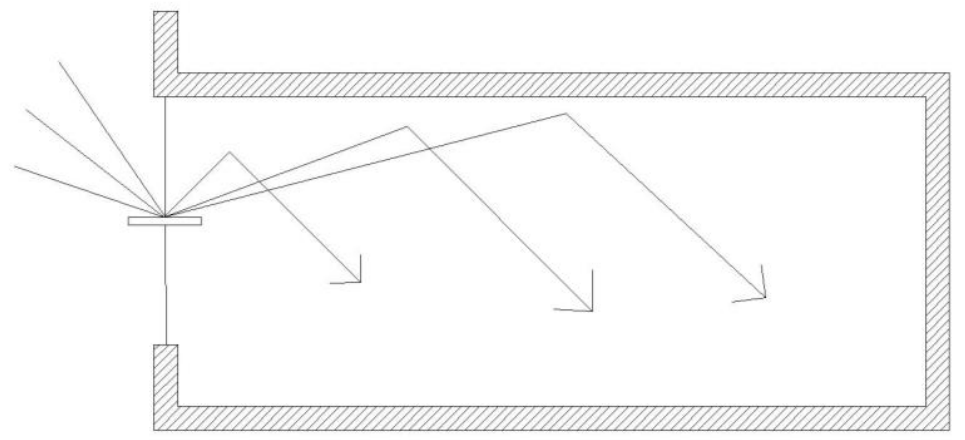

Figure 1a: Light shelf daylight distribution. Source: Abraham [7]

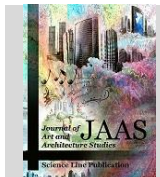



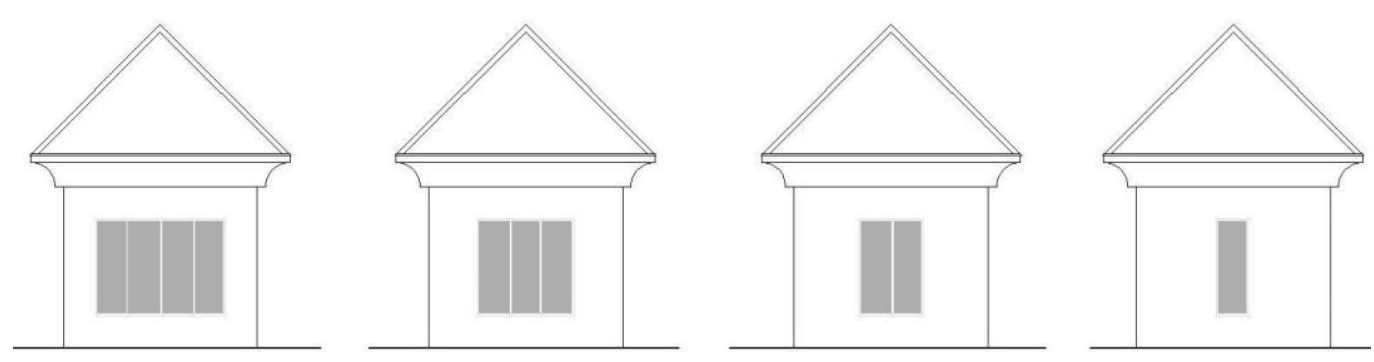

Figure 1b: Building aesthetics and window size
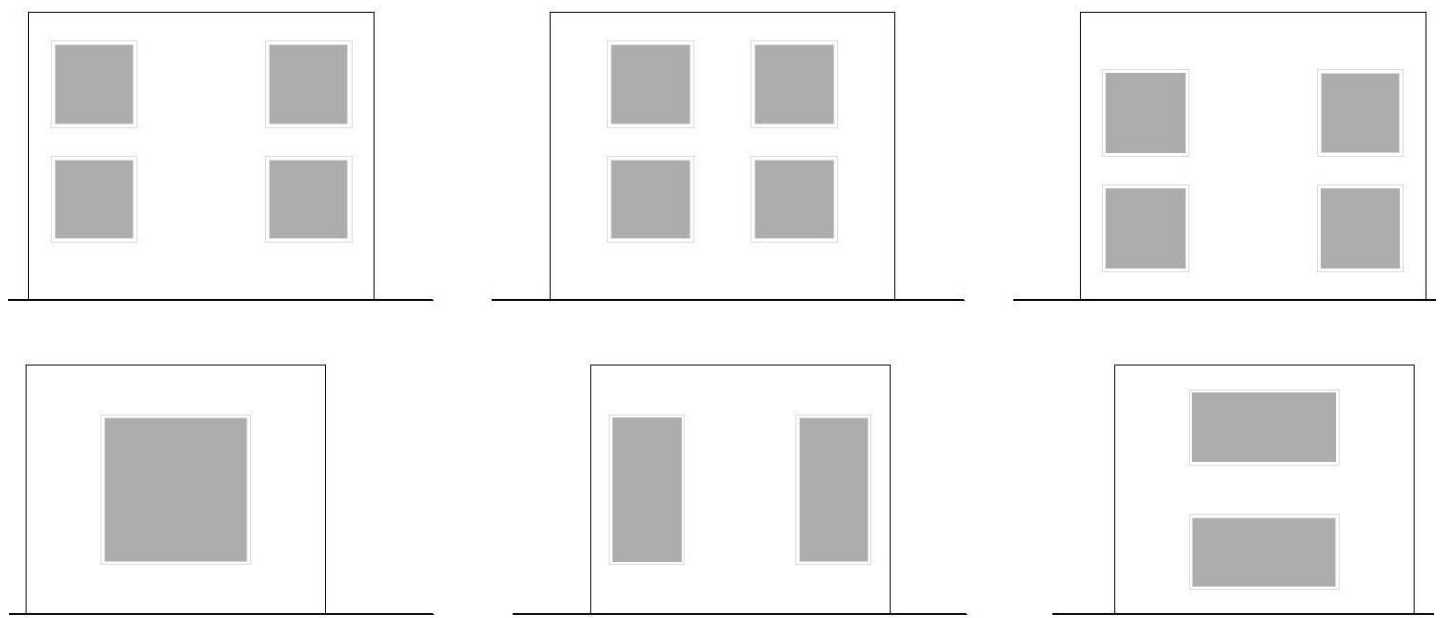

Figure 1c: Aesthetics, window distribution and placement on wall
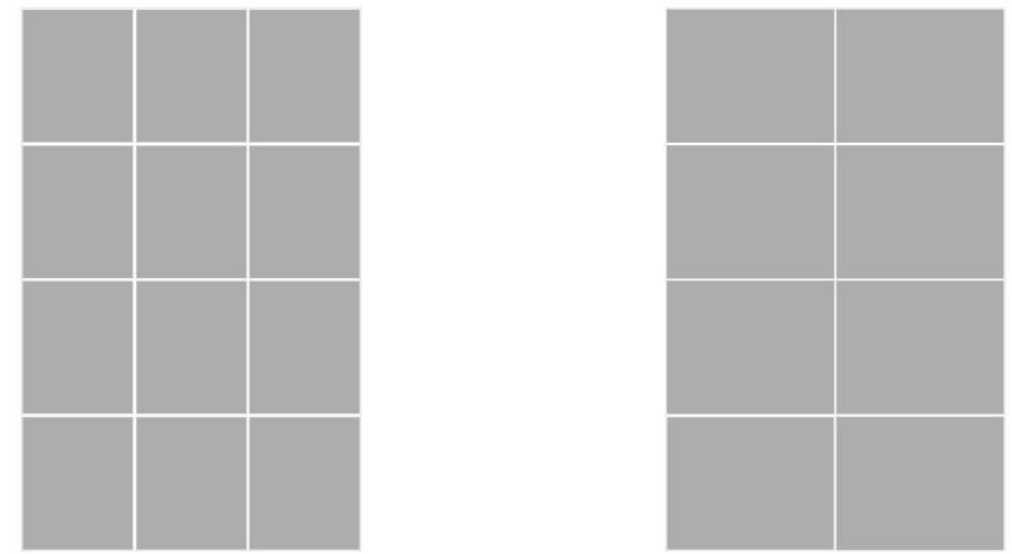

Figure 1d: Georgian (three panes) and Victorian (two panes) windows

\section{The research problem}

The prescriptive interpretation of "form follows function" [19] holds functional requirements to be more important than aesthetic considerations of buildings.

But for architects like Alberti and Ruskin [18], beauty was the overriding criterion in determining the success of a building; beauty is inseparable from suitability for use, and hence an aspect of utility.
Citation: Idowu O. M. and Humphrey S. (2018). Aesthetics and day-lighting correlation: an experimental study of form and placement of windows on buildings. $J$ Art Arch Stud. 7 (1): 01-10.

DOI: https://dx.doi.org/10.51148/jaas.2018.1
Given that daylight for visual comfort is one of the functional requirements of an architectural space influenced by form and position of windows, how much of it (day-lighting) is provided in a beautiful building'? In other words, what is the correlation between the daylight in spaces and the aesthetics of a building? This study elicits the nature and degree of correlation, if any, between the aesthetic and the day-lighting values of window forms and placement on buildings. 


\section{METHODOLOGY}

The investigation is a simulated experimental design as espoused in Groat and Wang [21]. It is a graphical simulation of the elevation of part of an existing Department of Architecture building. Five other elevations with same area but different form and position of windows were simulated, and the six elevations presented on A-4 paper-page (Figure 4). Physical architectural models of a room in the building were constructed with the six different forms and positions of windows on the external walls.

\section{Description of the study objects}

All the elevations (named G, H, J, K, L, and M) have same wall, room, and window areas but differ in the form (shape) and distribution (position) of their windows. Windows of the rooms on each elevation are of the same form and distribution. Elevation G has two windows each 1200 x $1200 m$ m, $1200 \mathrm{~mm}$ apart and 930mm above floor. Elevation $\mathrm{H}$ has two windows $1600 \mathrm{x} 900 \mathrm{~mm}$ each, $400 \mathrm{~mm}$ apart and 1230mm above floor. $\mathrm{J}$ and $\mathrm{K}$ have same window shape and spacing as $\mathrm{H}$, but different positions of $1830 \mathrm{~mm}$ and $630 \mathrm{~mm}$ respectively above floor level. L and M have one window each $2400 \mathrm{x}$ $1200 \mathrm{~mm}$ centrally placed along the wall length but of different height above floor level: 930mm and
$1530 \mathrm{~mm}$ respectively above floor level (Figures 2 to 4; Table 1).

A lux meter was deployed to measure daylight levels (DL) outside and on 16 designated points on the floor of the model rooms placed at window sill level indoors. Two out-of-the-model measurements were taken before and after the in-the-model measurements. Daylight factor (DF) for each of the model rooms were calculated as ratio of in-themodel mean daylight level to the average value outof-the-model.

Copies of the simulated elevations were produced and administered to the respondents who were mostly architectural educators and students. Weighted means were calculated to obtain the aggregated aesthetic 'weight' of each elevation by respondent groups. The mean daylight factors of the model rooms and the corresponding elevations' aesthetic weighted means were ranked in order of magnitude from the highest (ranked as $1^{\text {st }}$ ) to the lowest value (ranked as $6^{\text {th }}$ ). Aesthetic rankings by the four respondent groups were in-turn paired with the corresponding daylight factor rankings in order to establish any correlation. The Spearman's Rank Order Correlation Coefficients, as described in Koleoso [22], were calculated for the four groups. Values obtained were interpreted using the following rule of thumb: \pm 0.00 to \pm 0.19 , negligible; \pm 0.20 to \pm 0.39 , low; \pm 0.40 to \pm 0.59 , moderate; \pm 0.60 to \pm 0.79 , substantial; \pm 0.80 to \pm 0.99 , high; \pm 1 , perfect.

\begin{tabular}{lllllll}
\hline Table 1: Design attributes of the study objects & & & & \\
Window attributes & $\mathbf{G}$ & $\mathbf{H}$ & $\mathbf{J}$ & $\mathbf{K}$ & $\mathbf{L}$ & $\mathbf{M}$ \\
\hline $\begin{array}{l}\text { Geometry: } \\
\text { Ratio) }\end{array}$ & $\begin{array}{l}\text { Square } \\
(1: 1)\end{array}$ & $\begin{array}{l}\text { Rectangle } \\
(1: 1.8)\end{array}$ & $\begin{array}{l}\text { Rectangle } \\
(1: 1.8)\end{array}$ & $\begin{array}{l}\text { Rectangle } \\
(1: 1.8)\end{array}$ & $\begin{array}{l}\text { Rectangle } \\
(1: 2)\end{array}$ & $\begin{array}{l}\text { Rectangle } \\
(1: 2)\end{array}$ \\
\hline Dimension & $\begin{array}{l}1200 \mathrm{x} \\
1200 \mathrm{~mm}\end{array}$ & $\begin{array}{l}1600 \mathrm{x} \\
900 \mathrm{~mm}\end{array}$ & $\begin{array}{l}1600 \mathrm{x} \\
900 \mathrm{~mm}\end{array}$ & $\begin{array}{l}1600 \mathrm{x} \\
900 \mathrm{~mm}\end{array}$ & $\begin{array}{l}2400 \mathrm{x} \\
1200 \mathrm{~mm}\end{array}$ & $\begin{array}{l}2400 \mathrm{x} \\
1200 \mathrm{~mm}\end{array}$ \\
\hline Number & 2 & 2 & 2 & 2 & 1 & 1 \\
\hline $\begin{array}{l}\text { Horizontal } \\
\text { spacing }\end{array}$ & $400 \mathrm{~mm}$ & $400 \mathrm{~mm}$ & $400 \mathrm{~mm}$ & $400 \mathrm{~mm}$ & mid-wall length & mid-wall length \\
\hline Height above floor & $630 \mathrm{~mm}$ & $1230 \mathrm{~mm}$ & $1830 \mathrm{~mm}$ & $630 \mathrm{~mm}$ & $930 \mathrm{~mm}$ & $1530 \mathrm{~mm}$ \\
\hline
\end{tabular}

\section{RESULTS}

Table 2 shows the daylight levels (DL) and daylight factors (DF) in the model rooms of the simulated elevations G, H, H, K, L, and $\mathrm{M}$. The aesthetic rankings of the elevations according to respondent groups are indicated in tables 3 to 6 , while in table 7 are the correlation coefficients of the daylight factor of the elevation-rooms and aesthetic ranking of the elevations by respondent groups.

Daylight levels in elevation G-room range from 54.0 lux to 758.0 lux with mean value of 280.3 (and standard deviation, SD of 207.92 lux). The mean daylight factor for the room is 0.31. Elevation $\mathrm{H}$ room has daylight factor of 0.30 , daylight level range of 492.o lux, and mean daylight level of 267 lux. Observed in elevation J-room are daylight level range of 381.0 lux, mean value of 180.0 lux, and daylight factor of 0.20 . Daylight factor of 0.33 , daylight level range of 512.o lux, and mean daylight level of 284.5 lux were observed in elevation Kroom. In elevation L-room, observed were daylight factor of 0.34, mean daylight level of 310.3 (and SD of 236.7), and daylight level range of 759.0 lux. 585.0 lux was the range of daylight level observed in elevation M-room, while the means of daylight level and daylight factor in the room were 224.3 lux (and SD of 175.3) and 0.24 (SD of 0.18 ) respectively (Table 2).

The 300 level student respondents (Table 3) ranked the aesthetic appeals of elevations $\mathrm{G}, \mathrm{H}, \mathrm{J}, \mathrm{K}$, $\mathrm{L}$, and $\mathrm{M}$ as $4^{\text {th }}$ (mean rank weight of 3.71 ), $3^{\text {rd }}$ (mean rank weight of 3.84$), 6^{\text {th }}$ (mean rank weight of 1.84), $2^{\text {nd }}$ (mean rank weight of 4.32), $1^{\text {st }}$ (mean rank weight of 5.12), and $5^{\text {th }}$ (mean rank weight of 2.25), while their rankings by 500 level student 
respondents (in table 4) were $2^{\text {nd }}$ (mean rank weight of 4.18), $4^{\text {th }}$ (mean rank weight of 3.42 ), $6^{\text {th }}$ (mean rank weight of 2.24), $3^{\text {rd }}$ (mean rank weight of 4.02), $1^{\text {st }}$ (mean rank weight of 4.73 ), and $5^{\text {th }}$ (mean rank weight of 2.75). The elevations in the same order were ranked by the 600 level students (table 4 ) as $3^{\text {rd }}$ (mean rank weight of 4.06), $2^{\text {nd }}$ (mean rank weight of 4.26$), 6^{\text {th }}$ (mean rank weight of 1.84), $4^{\text {th }}$ (mean rank weight of 3.58$), 1^{\text {st }}$ (mean rank weight of 4.77), and $5^{\text {th }}$ (mean rank weight of 2.55); and were ranked by architects (table 5 ) as $2^{\text {nd }}$ (mean rank weight of $4.31), 4^{\text {th }}$ (mean rank weight of 3.38 ), $6^{\text {th }}$ (mean rank weight of 1.38), $3^{\text {rd }}$ (mean rank weight of 3.53$), 1^{\text {st }}$ (mean rank weight of 5.15), and $5^{\text {th }}$ (mean rank weight of 3.23).

The Spearman's Rank Order Correlation Coefficient of the daylight factor of the elevationrooms and aesthetic ranking of the elevations by 300 level student respondents (ARTS/DFR) was +0.94. Same values of correlation coefficient $(+0.94)$ were obtained for 500 level students and architects respondents groups, while the value obtained for 600 level students respondents was +0.77 .

\begin{tabular}{|c|c|c|c|c|c|c|c|c|c|c|c|c|}
\hline \multirow[t]{2}{*}{$\mathbf{S} / \mathbf{N}$} & \multicolumn{2}{|c|}{$\begin{array}{c}\text { Elevation G } \\
\text { Room }\end{array}$} & \multicolumn{2}{|c|}{$\begin{array}{l}\text { Elevation } \mathbf{H} \\
\text { Room }\end{array}$} & \multicolumn{2}{|c|}{$\begin{array}{l}\text { Elevation } \mathbf{J} \\
\text { Room }\end{array}$} & \multicolumn{2}{|c|}{$\begin{array}{l}\text { Elevation K } \\
\text { Room }\end{array}$} & \multicolumn{2}{|c|}{$\begin{array}{l}\text { Elevation L } \\
\text { Room }\end{array}$} & \multicolumn{2}{|c|}{$\begin{array}{l}\text { Elevation M } \\
\text { Room }\end{array}$} \\
\hline & DL & DF & DL & DF & DL & DF & DL & DF & DL & DF & DL & DF \\
\hline 1 & 65.00 & 0.07 & 41.00 & 0.05 & 39.00 & 0.04 & 51.00 & 0.06 & 31.00 & 0.03 & 30.00 & 0.03 \\
\hline 2 & 60.00 & 0.07 & 42.00 & o.05 & 44.00 & 0.05 & 46.00 & 0.05 & 47.00 & 0.05 & 35.00 & 0.04 \\
\hline 3 & 54.00 & 0.06 & 45.00 & 0.05 & 47.00 & 0.05 & 48.00 & 0.06 & 55.00 & 0.06 & 36.00 & 0.04 \\
\hline 4 & 84.00 & o.09 & 52.00 & o.06 & 44.00 & 0.05 & 55.00 & 0.06 & 42.00 & 0.05 & 34.00 & 0.04 \\
\hline 5 & 758.00 & 0.83 & 361.0 & 0.40 & 72.00 & 0.08 & 485.0 & 0.56 & 367.0 & 0.40 & 76.00 & 0.08 \\
\hline 6 & 108.00 & 0.12 & 267.0 & 0.30 & 69.00 & 0.08 & 230.0 & 0.27 & 790.0 & 0.86 & 232.0 & 0.24 \\
\hline 7 & 457.00 & 0.50 & 369.0 & 0.41 & 73.00 & 0.08 & 398.0 & 0.46 & 732.0 & 0.80 & 231.0 & 0.24 \\
\hline 8 & 554.00 & 0.60 & 319.0 & 0.36 & 69.00 & 0.08 & 363.0 & 0.42 & 201.0 & 0.22 & 80.00 & 0.08 \\
\hline 9 & 403.00 & 0.44 & 333.0 & o.37 & 281.0 & 0.31 & 335.0 & 0.39 & 355.0 & 0.39 & 249.0 & 0.26 \\
\hline 10 & 385.00 & 0.42 & 413.0 & 0.46 & 288.0 & 0.32 & 513.0 & 0.59 & 582.0 & 0.63 & 503.0 & 0.53 \\
\hline 11 & 186.00 & 0.20 & 409.0 & 0.46 & 297.0 & 0.33 & 395.0 & 0.46 & 481.0 & 0.52 & 615.0 & 0.65 \\
\hline 12 & 496.00 & 0.54 & 533.0 & 0.60 & 420.0 & 0.47 & 558.0 & 0.65 & 235.0 & 0.26 & 291.0 & 0.31 \\
\hline 13 & 267.00 & 0.29 & 288.0 & 0.32 & 309.0 & 0.34 & 291.0 & 0.34 & 193.0 & 0.21 & 220.0 & 0.23 \\
\hline 14 & 194.00 & 0.21 & 294.0 & 0.33 & 317.0 & 0.35 & 284.0 & 0.33 & 315.0 & 0.34 & 313.0 & 0.33 \\
\hline 15 & 209.00 & 0.23 & 299.0 & 0.34 & 293.0 & 0.33 & 284.0 & 0.33 & 323.0 & 0.35 & 395.0 & 0.41 \\
\hline 16 & 205.00 & 0.22 & 208.0 & 0.23 & 218.0 & 0.24 & 216.0 & 0.25 & 216.0 & 0.23 & 250.0 & 0.26 \\
\hline Range & 704.0 & - & 492.0 & - & 381.0 & - & 512.0 & - & 759.0 & - & 585.0 & - \\
\hline Mn & 280.31 & 0.31 & 267.0 & 0.30 & 180.0 & 0.20 & 284.5 & 0.33 & 310.3 & 0.34 & 224.3 & 0.24 \\
\hline SD & 207.92 & 0.23 & 150.8 & 0.17 & 132.9 & 0.15 & 169.0 & 0.20 & 236.7 & 0.26 & 175.3 & 0.18 \\
\hline Rank & \multicolumn{2}{|c|}{3 rd } & \multicolumn{2}{|c|}{ 4th } & \multicolumn{2}{|c|}{ 6th } & \multicolumn{2}{|c|}{ 2nd } & \multicolumn{2}{|c|}{ 1st } & \multicolumn{2}{|c|}{$5^{\text {th }}$} \\
\hline
\end{tabular}

\begin{tabular}{|c|c|c|c|c|c|c|c|c|c|}
\hline \multirow{2}{*}{$\mathbf{S} / \mathbf{N}$} & \multirow{2}{*}{ Subject } & \multicolumn{6}{|c|}{ Rating frequency positions/(weigth) } & \multirow{2}{*}{$\begin{array}{l}\text { Mean } \\
\text { weight }\end{array}$} & \multirow{2}{*}{$\begin{array}{l}\text { Mean } \\
\text { rank }\end{array}$} \\
\hline & & $1^{\text {st }}(6)$ & $2^{\text {nd }}(5)$ & $3^{\text {rd }}(4)$ & $4^{\text {th }}(3)$ & $5^{\text {th }}(2)$ & $6^{\text {th }}(1)$ & & \\
\hline 1 & Elevation $\mathrm{G}$ & 6 & 10 & 17 & 12 & 4 & 6 & 3.71 & $4^{\text {th }}$ \\
\hline 2 & Elevation $\mathrm{H}$ & 5 & 14 & 12 & 19 & 4 & 2 & 3.84 & $3 \mathrm{rd}$ \\
\hline 3 & Elevation J & 1 & 1 & 4 & 3 & 19 & 27 & 1.84 & $6^{\text {th }}$ \\
\hline 4 & Elevation $\mathrm{K}$ & 14 & 12 & 11 & 15 & 2 & 1 & 4.32 & $2^{\text {nd }}$ \\
\hline 5 & Elevation L & 30 & 11 & 9 & 2 & 2 & 1 & 5.12 & $1^{\text {st }}$ \\
\hline 6 & Elevation M & 1 & 6 & 3 & 3 & 20 & 22 & 2.25 & $5^{\text {th }}$ \\
\hline
\end{tabular}

\begin{tabular}{|c|c|c|c|c|c|c|c|c|c|}
\hline \multirow{2}{*}{$\mathbf{S} / \mathbf{N}$} & \multirow{2}{*}{ Subject } & \multicolumn{6}{|c|}{ Rating frequency positions/(weigth) } & \multirow{2}{*}{$\begin{array}{l}\text { Mean } \\
\text { weight }\end{array}$} & \multirow{2}{*}{$\begin{array}{l}\text { Mean } \\
\text { rank }\end{array}$} \\
\hline & & $1^{\text {st }}(6)$ & $2^{\text {nd }}(5)$ & $3^{\text {rd }}(4)$ & $4^{\text {th }}(3)$ & $5^{\text {th }}(2)$ & $6^{\text {th }}(1)$ & & \\
\hline 1 & Elevation $\mathrm{G}$ & 8 & 14 & 9 & 7 & 3 & 3 & 4.18 & $2^{\text {nd }}$ \\
\hline 2 & Elevation $\mathrm{H}$ & 6 & 4 & 7 & 16 & 10 & 2 & 3.42 & $4^{\text {th }}$ \\
\hline 3 & Elevation J & 3 & 1 & 5 & 5 & 9 & 20 & 2.24 & $6^{\text {th }}$ \\
\hline 4 & Elevation $\mathrm{K}$ & 8 & 9 & 14 & 5 & 5 & 3 & 4.02 & $3^{\text {rd }}$ \\
\hline 5 & Elevation L & 21 & 8 & 7 & 3 & 4 & 2 & 4.73 & $1^{\text {st }}$ \\
\hline 6 & Elevation M & 3 & 7 & 3 & 7 & 11 & 13 & 2.75 & $5^{\text {th }}$ \\
\hline
\end{tabular}




\begin{tabular}{|c|c|c|c|c|c|c|c|c|c|}
\hline \multirow{2}{*}{$\mathbf{S} / \mathbf{N}$} & \multirow{2}{*}{ Subject } & \multicolumn{6}{|c|}{ Rating frequency positions/(weigth) } & \multirow{2}{*}{$\begin{array}{l}\text { Mean } \\
\text { weight }\end{array}$} & \multirow{2}{*}{$\begin{array}{l}\text { Mean } \\
\text { rank }\end{array}$} \\
\hline & & $1^{\text {st }}(6)$ & $2^{\text {nd }}(5)$ & $3^{\text {rd }}(4)$ & $4^{\text {th }}(3)$ & $5^{\text {th }}(2)$ & $6^{\text {th }}(1)$ & & \\
\hline 1 & Elevation G & 5 & 9 & 9 & 3 & 1 & 4 & 4.06 & $3^{\text {rd }}$ \\
\hline 2 & Elevation $\mathrm{H}$ & 7 & 9 & 3 & 9 & 3 & o & 4.26 & $2^{\text {nd }}$ \\
\hline 3 & Elevation J & 2 & O & 1 & 4 & 5 & 19 & 1.84 & $6^{\text {th }}$ \\
\hline 4 & Elevation $\mathrm{K}$ & 4 & 5 & 6 & 10 & 2 & 4 & 3.58 & $4^{\text {th }}$ \\
\hline 5 & Elevation L & 12 & 7 & 7 & 3 & 2 & o & 4.77 & $1^{\mathrm{St}}$ \\
\hline 6 & Elevation M & 1 & 2 & 5 & 1 & 18 & 4 & 2.55 & $5^{\text {th }}$ \\
\hline
\end{tabular}

\begin{tabular}{|c|c|c|c|c|c|c|c|c|c|}
\hline \multirow{2}{*}{$\mathbf{S} / \mathbf{N}$} & \multirow{2}{*}{ Subject } & \multicolumn{6}{|c|}{ Rating frequency positions/(weigth) } & \multirow{2}{*}{$\begin{array}{l}\text { Mean } \\
\text { weight }\end{array}$} & \multirow{2}{*}{$\begin{array}{l}\text { Mean } \\
\text { rank }\end{array}$} \\
\hline & & $1^{\mathrm{st}}(6)$ & $2^{\text {nd }}(5)$ & $3^{\text {rd }}(4)$ & $4^{\text {th }}(3)$ & $5^{\text {th }}(2)$ & $6^{\text {th }}(1)$ & & \\
\hline 1 & Elevation G & 3 & 2 & 6 & 1 & 0 & 1 & 4.31 & $2^{\text {nd }}$ \\
\hline 2 & Elevation $\mathrm{H}$ & o & 4 & 2 & 4 & 1 & 2 & 3.38 & $4^{\text {th }}$ \\
\hline 3 & Elevation J & 0 & o & o & 0 & 5 & 8 & 1.38 & $6^{\text {th }}$ \\
\hline 4 & Elevation $\mathrm{K}$ & 3 & o & 3 & 4 & 1 & 2 & 3.53 & $3^{\text {rd }}$ \\
\hline 5 & Elevation L & 7 & 3 & 1 & 2 & 0 & 0 & 5.15 & $1^{\mathrm{S}}$ \\
\hline 6 & Elevation M & o & 4 & 1 & 2 & 6 & o & 3.23 & $5^{\text {th }}$ \\
\hline
\end{tabular}

\begin{tabular}{lcccc}
\hline \multicolumn{2}{c}{ Table 7: Correlation of aesthetic and daylight factor rankings (DFR) } & & \\
& ARTS/DFR & ARFS/DFR & ARSS/DFR & ARAR/DFR \\
\hline${ }^{*}$ SROCC & +0.94 & +0.94 & +0.77 & +0.94 \\
\hline Remarks & High & High & Substantial & High \\
\hline
\end{tabular}

${ }^{*}$ Spearman's Rank Order Correlation Coefficient.

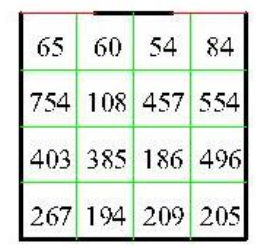

Floor Plan

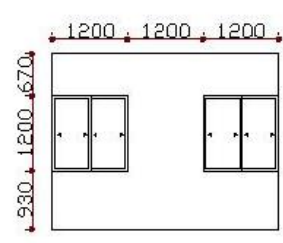

Elevation

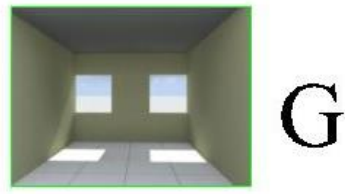

Interior View

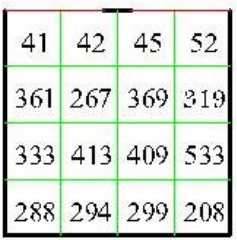

Floor Plan

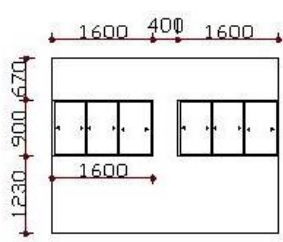

Elevation

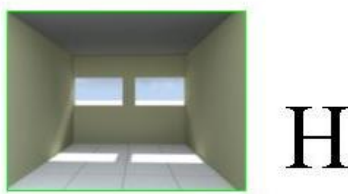

Interior View

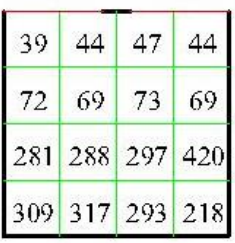

Floor Plan

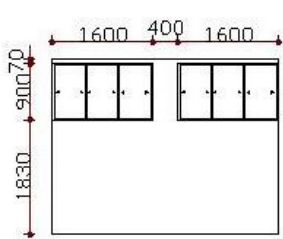

Elevation

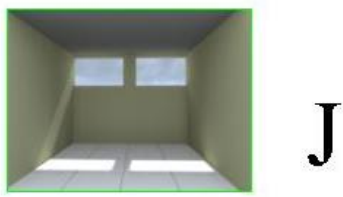

Interior View

Figure 2: Details of simulated rooms with elevations G, H, and J.

Citation: Idowu O. M. and Humphrey S. (2018). Aesthetics and day-lighting correlation: an experimental study of form and placement of windows on buildings. $J$ Art Arch Stud. 7 (1): 01-10.

DOI: https://dx.doi.org/10.51148/jaas.2018.1 


\begin{tabular}{|c|c|c|c|}
\hline 51 & 46 & 48 & 55 \\
\hline 485 & 230 & 398 & 363 \\
\hline 335 & 513 & 395 & 558 \\
\hline 291 & 284 & 284 & 216 \\
\hline
\end{tabular}

Floor Plan

\begin{tabular}{|c|c|c|c|}
\hline 31 & 47 & 55 & 42 \\
367 & 790 & 732 & 201 \\
\hline 355 & 582 & 481 & 235 \\
193 & 315 & 323 & 216 \\
\hline
\end{tabular}

Floor Plan

\begin{tabular}{|c|c|c|c|}
\hline 30 & 35 & 36 & 34 \\
\hline 76 & 232 & 231 & 80 \\
\hline 249 & 503 & 615 & 291 \\
220 & 313 & 395 & 250 \\
\hline
\end{tabular}

Floor Plan

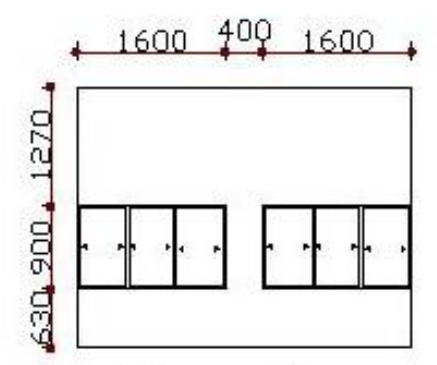

Elevation

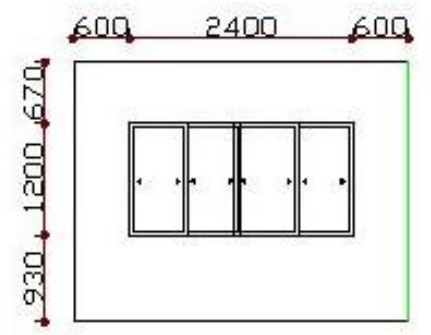

Elevation

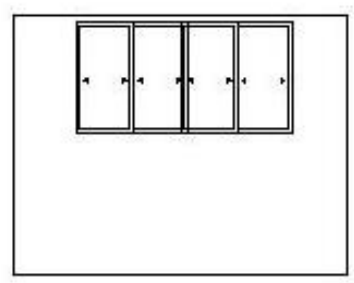

Elevation

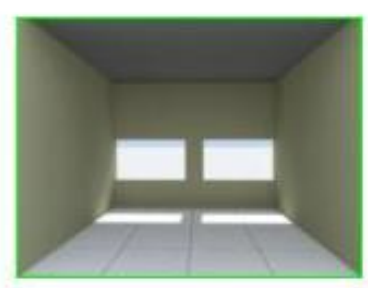

$\mathrm{K}$

Interior View

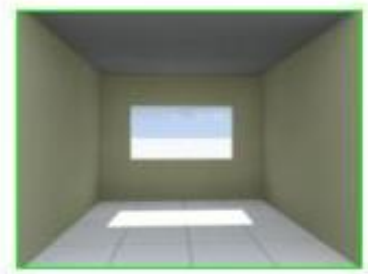

$\mathrm{L}$

Interior View

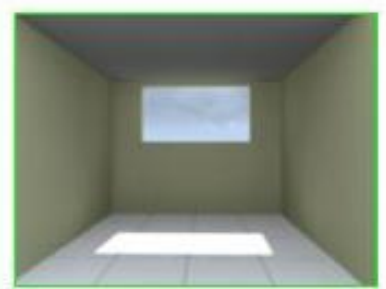

M

Interior View

Figure 2: Details of simulated rooms with elevations G, H, and J. 

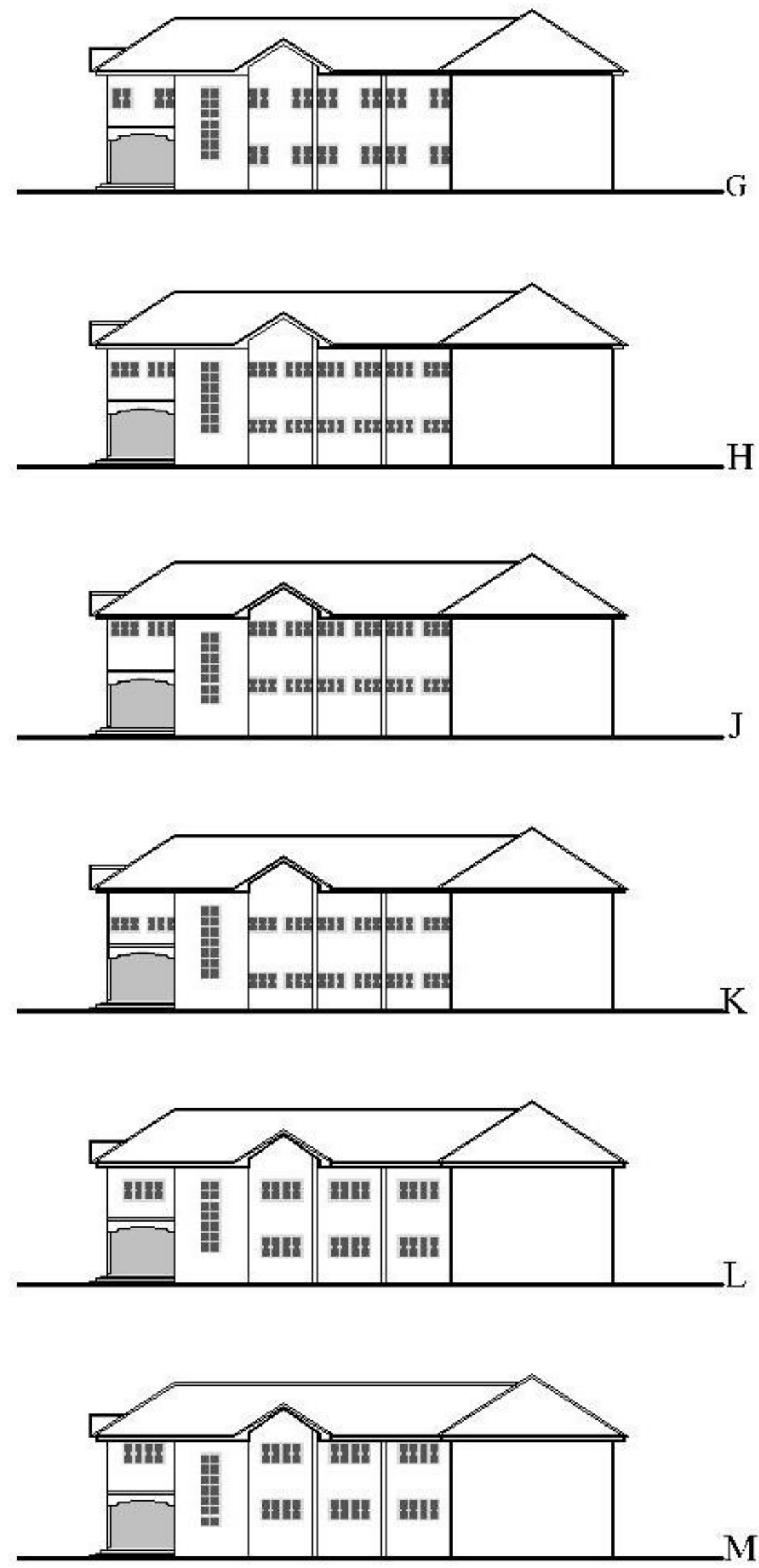

Figure 4: Simulated elevations of part of an existing building.

Citation: Idowu O. M. and Humphrey S. (2018). Aesthetics and day-lighting correlation: an experimental study of form and placement of windows on buildings. $J$ Art Arch Stud. 7 (1): 01-10.

DOI: $\underline{\text { https://dx.doi.org/10.51148/jaas.2018.1 }}$
Journal of Art and Architecture Studies (JAAS)

ISSN: 2383-1553

Volume 7, No. 1: 01-10. 2018 SCIENCE LINE 


\section{DISCUSSION}

The results reveal differences in mean and individual floor-bay values of daylight level and daylight factor in the rooms under study. Whether these differences are significant or not, they suggest that one or the two window design variables (form and position) under study affect daylight quality and quantity. The effect of individual variables may be appreciated by paired comparison of daylight in rooms with windows of only one different design parameter. For instance, comparisons of elevation $\mathrm{H}-$ and J-rooms, and $\mathrm{L}-$ and M-rooms reveal that windows at higher level conduced to lower mean daylight levels (DL) and daylight factors (DF) on the room floor. It also shows that daylight is more evenly distributed (of better quality) on the floor of rooms with higher level windows. A comparison of $\mathrm{H}$ - and $\mathrm{K}-$ rooms (having same window form) also reveals the same pattern of more evenly distributed daylight on floor of room with higher window level.

A comparison of G- and L-rooms (of same widow height) reveal that L-room with a rectangular window-form conduce to higher values of daylight level and daylight factor than G-room with two (smaller) square window-forms. However, daylight levels are more evenly distributed in the room with two smaller (square) windows than in the room with one rectangular window.

The aesthetic rankings of the elevations are also different, again suggesting that one or the two variables under study (window form and position) affect aesthetics. There is some level of consistency in the rankings among the respondent groups. For instance elevations $\mathrm{J}, \mathrm{L}$, and $\mathrm{M}$ were ranked as $6^{\text {th }}$, $1^{\text {st }}$, and $5^{\text {th }}$ respectively by the four respondent groups. L and M have same window form but differ only in window vertical position on wall. Their aesthetic ranking gap ( $1^{\text {st }}$ to $\left.5^{\text {th }}\right)$ seem too wide to ignore, and this is suggestive of a significant aesthetic effect of window vertical position on wall. The same pattern is noticeable between $\mathrm{J}$ and $\mathrm{H}$ having same form but different window positions on wall. Lower aesthetic values are observed as window moves vertically away from the centre of wall. $L$ and $\mathrm{G}$ are of the same height but different window forms, and were ranked seemingly different in aesthetic appeals, also suggesting that window form has effect on aesthetics. The ratio of the rectangular window $(1: 2)$ in $\mathrm{L}$ is closer to the golden ratio (1: 1.62) than that of square windows (1:1) in G. This result concurs with Lidwell et al. [12] and Idowu and Okonkwo [20], and further strengthens the aesthetic harmony theory of the golden ratio.

The Spearman's Rank Order Correlation Coefficients of +0.94 in three of the four ranking groups and +0.77 in one suggest that there is a high positive correlation between aesthetics and daylight design of windows on walls. It indeed reinforces the believe $[12,13]$ that attractive things work better or beautiful forms are more functional (form follows function).

\section{CONCLUSION AND RECOMMENDATIONS}

The study attempted to ascertain the effects of window forms and positions on day-lighting and aesthetics of buildings.

It was revealed that rooms with a rectangular window-form conduce to higher values of daylight level and daylight factor than those with two (smaller) square window-forms. However, daylight levels are more evenly distributed in the room with two smaller (square) windows than in the room with one rectangular window.

It was also found that windows at higher level conduced to lower mean daylight levels (DL) and daylight factors (DF) on the room floor. It also shows that daylight is more evenly distributed (of better quality) on the floor of rooms with higher level windows.

Window forms and vertical positions on walls were also found to affect aesthetic ranking of buildings. Aesthetic ranking stepped up as window form got closer to the golden ratio; lower aesthetic values were observed as window moved vertically away from the centre of wall. A high or an appreciable and positive correlation between aesthetics and daylight design of windows on walls was discovered in the study. To enhance aesthetics and daylight through window designs, it is recommended that: (i) windows form be of rectangular geometry of proportion close to the golden ratio; (ii) windows be positioned to minimise eccentricity on individual room-walls.

\section{DECLARATIONS}

\section{Authors' Contributions}

All authors have directly participated in the planning, execution, or analysis of this study, and have read and approved the final version submitted.

\section{Competing interests}

The authors declare that they have no competing interests.

\section{REFERENCES}

[1] Nick Z (2007). Aesthetic judgement. In: Stanford encyclopaedia of philosophy.

[2] Architecture-student (n.d): Aesthetic components of architecture. Online: Retrieved $15^{\text {th }}$ April 2011. http://www.architecture-student.com/tag/aesthetics.

[3] Lang J (1987). Creating architectural theory: The role of the behavioural sciences in environmental design. New York: Van Nostrand Reinhold. Google Scholar

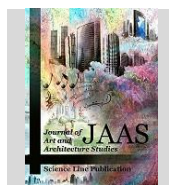


[4] New World Encyclopaedia (n.d): Aesthetics. Retrieved October 31, retrieved from: www.newworldencyclopedia.org/entry

[5] Architeacher (2002). Aesthetics. Centre for the Study of Art and Architecture. Retrieved 2015, retrieved from: http://www.architeacher.org/aesthetics/archimain.html.

[6] Harrold RM (1983). Daylight. In: Callender, J. H. (Ed): Time saver standards for architectural design data. Singapore: McGraw-Hill, Inc. Google Scholar

[7] Abraham LE (1996). Daylighting. In Gottfried, D. A., and Simon, L. N. (Eds.): Sustainable building technical manual. U. S. A.: Public Technology, Inc. Google Scholar

[8] Rich P and Dean Y (1999). Principles of element design: windows. London: Architectural Press. Google Scholar

[9] Gyimah KA and Tetlow D (2014): Achieving energy efficiency and aesthetics through windows in the Tropics. Google Scholar; https://doi.org/10.26796/jenrm.v1i1.42

[10] Apogee Enterprises (2015). Chicago's Prudential Tower I replaces windows for updated aesthetics, tenant comfort, energy-efficiency. Retrieved October 31, 2016 from: http://www.apog.com

[11] Odim OO, Okonkwo MM and Idowu OM (2012). Thermal comfort passive design. AARCHES monographic series, 2. Google Scholar

[12] Moscoso CP (2016). Daylighting and architectural quality: Aesthetic perception of daylight indoor environment. Retrieved Oct. 30 from: http://hdl.handle.net/11250/2379863 ; Google $\underline{\text { Scholar }}$

[13] Burberry P (1979). Environment and Services. New York: B. T. Batsford Limited. Google Scholar

[14] Kendall D (2011): Aesthetic and happiness: How space affects well-being. Retrieved October 30 from: www.huffingtonpost.com/dylan-kendal.

[15] Efficient Windows Collaborative (2016). Design considerations for window performance. Retrieved October 31 from: www.efficientwindows.org/design.php

[16] Ching F (2007). Architecture: Form, space and order. New York: John Wiley \& Sons Inc. Google $\underline{\text { Scholar }}$

[17] Smith PF (2003). The dynamics of delight: Architecture and aesthetics. London: Routledge. Google Scholar

[18] Hearn MF (2003). Ideas that shaped buildings. London: The MIT Press. Google Scholar

[19] Lidwell W, Holden K and Butler J. (2003). Universal principles of design. Massachusetts: Rockport Publishers. Google Scholar

[20] Idowu OM and Okonkwo MM (2011): Aesthetic effect of building's structural forms: An experimental study of columns, beams, arches, and triangular pseudo-arches. Environmental Review, 4(2). Google Scholar

[21] Groat L and Wang D (2002). Architectural research methods. New York: John Wiley and Sons Inc. Google Scholar

[22] Koleoso A (1999). Research methods and statistics. Ondo: Alex Publishers.
Citation: Idowu O. M. and Humphrey S. (2018). Aesthetics and day-lighting correlation: an experimental study of form and placement of windows on buildings. $J$ Art Arch Stud. 7 (1): 01-10. 